\title{
A Tale of Two Tails: Tail Bifurcation in the Common House Gecko, Hemidactylus frenatus (Duméril and Bibron 1836), in Bangladesh
}

\author{
Naim Khandakar ${ }^{1}$ and Irin Sultana \\ 1Department of Zoology, Jagannath University, Dhaka-1100, Bangladesh (naim.jnu.2014@gmail.com) \\ ${ }^{2}$ National Centre for Biological Sciences, Bangalore-560065, Karnataka, India
}

$\mathrm{T}_{\mathrm{a}}^{\mathrm{a}}$ ail bifurcation occurs when the tail duplicates as it regrows after any mechanical damage. This is relatively rare in nature (Kornilev et al. 2018), although tail bifurcation has been reported in a number of amphibian and reptilian species (e.g., Ananjeva and Danov 1991; Kumbar et al. 2011; Mitchell et al. 2012; Conzendey et al. 2013; Cordes and Walker 2013; Martins et al. 2013; Mata-Silva et al. 2013; Vrcibradic and Niemeyer 2013; Dudek and Ekner-Grzyb 2014; Passos et al. 2014; Plessey et al. 2014; Pelegrin and Leão 2016; Hass et al.

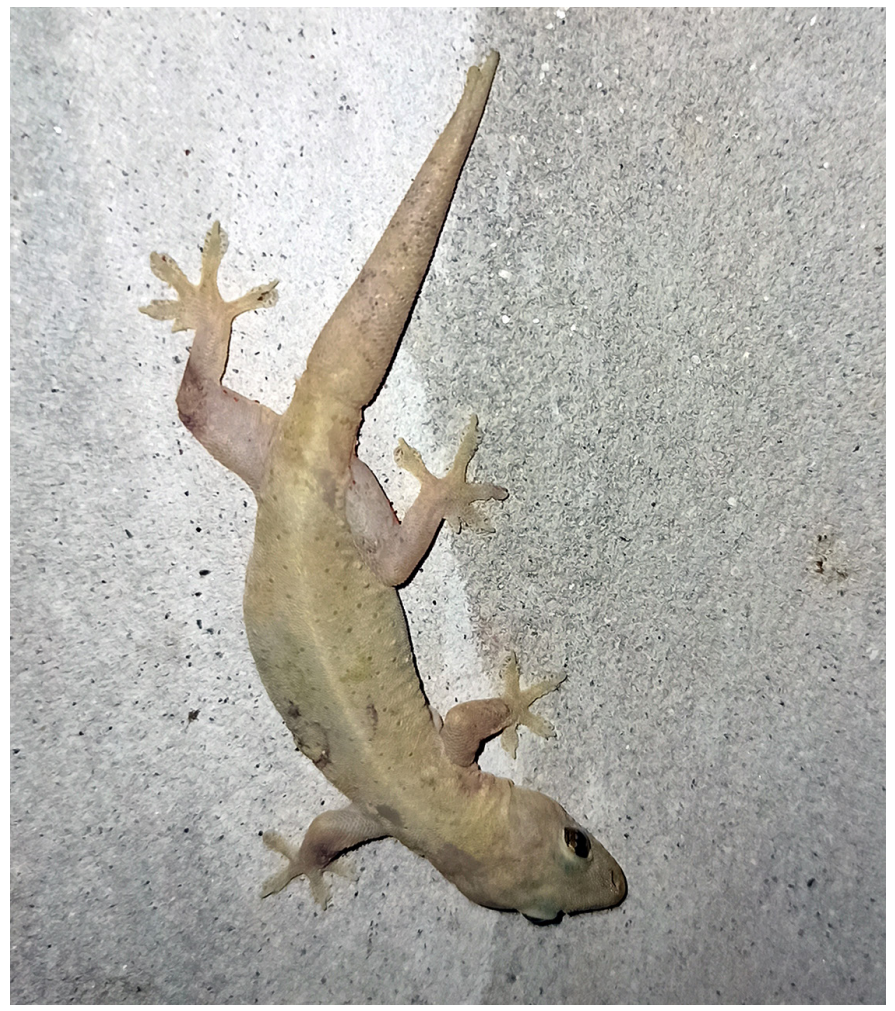

Fig. 1. A Common House Gecko (Hemidactylus frenatus) with a bifurcated tail. Photographs by Naim Khandakar.
2018). Tail bifurcation often is a consequence of caudal autotomy, a defensive mechanism used mainly by salamanders and lizards in which a portion of the tail is detached in response to a predation attempt (e.g., Meyer et al. 2002; Bateman and Fleming 2009; Vitt and Caldwell 2009). Tail bifurcation in Common House Geckos (Hemidactylus frenatus) has been reported only five times throughout the world (Chan et al. 1984; Khan 2004; García-Vinalay et al. 2017; Heyborne and Mehan 2017; Maria and Razi 2018).

Hemidactylus frenatus is the most abundant gecko in Bangladesh (Khan 2004; Hasan et al. 2014; Khandakar et al. 2020), where it is widely distributed in diverse habitats, including forests and human settlements in both rural and urban areas (Hasan 2015; Khandakar et al. 2020). At 2028 h on 8 February 2020, we observed a gecko about $5 \mathrm{~m}$ above the ground on the wall of the IUCN field office in the Nijhum Dweep National Park and Marine Protected Area in Bangladesh $\left(22.07625^{\circ} \mathrm{N}, 91.05952 \mathrm{E}\right)$. This $163.52-\mathrm{km}^{2}$ coastal island with a planted mangrove ecosystem is located in the northern portion of the lower Meghna Estuary and south of Hatiya Island in the Bay of Bengal (Iftekhar and Takama 2008; Hossain et al. 2016; Sultana et al. 2020). Upon closer observation, we noticed that this gecko had a bifurcated tail, with the additional tail $5 \mathrm{~mm}$ from the tip of the main tail (Fig. 1). This note is the third report of tail bifurcation in $H$. frenatus in Bangladesh.

\section{Acknowledgements}

We thank the Bangladesh Forest Department, Jagannath University (Dhaka, Bangladesh), National Centre for Biological Sciences (Bangalore, India), IUCN Bangladesh, Delip K. Das, Dr. Suhel Quader, Dr. Ashwin Viswanathan, and Dr. Sabir Bin Muzaffar for logistical, financial, and moral support during this study. 


\section{Literature Cited}

Ananjeva, N.B. and R.A. Danov. 1991. A rare case of bifurcated caudal regeneration in the Caucasian agama, Stellio caucasius. Amphibia-Reptilia 12: 343-349.

Bateman, P.W. and P.A. Fleming. 2009. To cut a long tail short: a review of lizard caudal autotomy studies carried out over the last 20 years. Journal of Zoology 277: 1-14.

Chan, J.G., L.L. Young., P.R.K. Chang., C.M. Shero, and C. Watts. 1984. Morphological anomalies of two geckos, Hemidactylus frenatus and Lepidodactylus lugubris, and the toad, Bufo marinus, on the Island of Hawaii, pp. 41-50. In: C.W. Smith (ed.), Proceedings of the Fifth Conference in Natural Sciences. Hawaii Volcanoes National Park, 5-7 June 1984. Department of Botany, University of Hawaii at Manoa, Honolulu, Hawaii.

Conzendey, P., S.P.S. Campos, F.M. Lanna, J.D.C.G. De Amorim, and B.M. De Sousa. 2013. Ophiodes striatus (Striped Worm Lizard). Bifurcated tail. Herpetological Review 44: 145-146.

Cordes, J.E. and J.M. Walker. 2013. Aspidoscelis velox (Plateau Striped Whiptail). Bifurcation. Herpetological Review 44: 319.

Dudek, K. and A. Ekner-Grzyb. 2014. Field observation of two-tailed sand lizard Lacerta agilis Linnaeus, 1758 and a common lizard Zootoca vivipara (Jacquin, 1787) in Poland. Natura Sloveniae 16: 65-66.

García-Vinalay, A. 2017. Hemidactylus frenatus Duméril \& Bibron, 1836. Tail bifurcation. Mesoamerican Herpetology 4: 635-637.

Haas, S.E., M.K. Reeves, A.E. Pinkney, and P.T.J. Johnson. 2018. Continentalextent patterns in amphibian malformations linked to parasites, chemical contaminants, and their interactions. Global Change Biology 24: e275-e288.

Hasan, M.K. 2015. Hemidactylus frenatus, p. 115. In: IUCN Bangladesh, Red List of Bangladesh Volume 4: Reptiles and Amphibians. IUCN, International Union for Conservation of Nature, Bangladesh Country Office, Dhaka, Bangladesh.

Hasan, M.K., M.M.H. Khan, and M.M Feeroz. 2014. Amphibians and Reptiles of Bangladesh - A Field Guide. Arannayk Foundation, Dhaka, Bangladesh.

Heyborne, W.H. and A. Mahan. 2017. Hemidactylus frenatus (Common House Gecko). Tail bifurcation. Herpetological Review 48: 437-438.

Hossain, K.T., M. Salauddin, and I.A. Tanim. 2016. Assessment of the dynamics of coastal island in Bangladesh using geospatial techniques: domar char. Journal of the Asiatic Society of Bangladesh Science 42: 219-228.

Iftekhar, S. and T. Takama. 2008. Perceptions of biodiversity, environmental services, and conservation of planted mangroves: A case study on Nijhum Dwip
Island, Bangladesh. Wetlands Ecology and Management 16: 119-137.

Khan, M.A.R. 2004. Checklist of Herpetofauna of Bangladesh. Cobra 75: 1-29.

Khandakar, N., K.N. Jeny, and D.K. Das. 2020. Limb-loss in a Common House Gecko (Hemidactylus frenatus Duméril and Bibron 1836) from Bangladesh. Reptiles \& Amphibians 26: 240.

Kornilev, Y.V., G. Popgeorgiev, E. Vacheva, and N. Tzankov. 2018. First records of melanism (including in tail bifurcation) of lacertid lizards (Reptilia: Lacertidae) in Bulgaria. North-Western Journal of Zoology 14: 142-144.

Kumbar, S.M., A.B. Ghadage, and V.M. Shndage. 2011. Hemidactylus flaviviridis (House Gecko). Bifurcation. Herpetological Review 42: 94.

Martins, R.L., P.G. Peixoto, P.H.M. Fonseca, A.G. Martinelli, W.R. Silva, and A. Pelli. 2013. Abnormality in the tail of the collated lizard Tropidurus gr. torquatus (Iguania, Tropiduridae) from Uberaba city, Minas Gerais State, Brazil. Herpetology Notes 6: 369-371.

Maria, M. and H.A. Razi. 2018. Observation of tail bifurcation in Hemidactylus frenatus (Schlegel, 1836). Herpetology Notes 11: 953-954.

Mata-Silva, V., A. Rocha, J.D. Johnson, and L.D. Wilson. 2013. Urosaurus bicarinatus (Tropical Tree Lizard). Bifurcation. Herpetological Review 44: 686-687.

Meyer, V., M.R. Preest, and S.M. Lochetto. 2002. Physiology of original and regenerated lizard tails. Herpetologica 58: 75-86.

Mitchell, J.C., W. McDaniel, and J. McDaniel. 2012. Plestiodon inexpectatus (Southeastern Five-lined Skink). Bifurcation. Herpetological Review 43: 650.

Passos, D.C., L.T. Pinheiro, C.A.B Galdino, and C.F.D. Rocha. 2014. Tropidurus semitaeniatus (Calango de Lagedo). Tail bifurcation. Herpetological Review 45: 138.

Plessey, H., P. Smith, J.-P Brouard, and K. Atkinson. 2014. Vanzosaura rubricauda (Red-tailed Vanzosaur). Bifurcation and trifurcation. Herpetological Review 45: 138-139.

Pelegrin, N. and S.M. Leão. 2016. Injured Salvator merianae (Teiidae) regenerates six tails in central Argentina. Cuadernos de Herpetología 30: 21-23.

Sultana, I., N. Khandakar, and D.K. Das. 2020. Distribution of the Many-lined Grass Skink, Eutropis multifasciata (Kuhl 1820), in Bangladesh. Reptiles \& Amphibians 27: 111.

Vitt, L.J. and J.P. Caldwell. 2009. Herpetology: An Introductory Biology of Amphibians and Reptiles. 3rd ed. Academic Press, San Diego, California.

Vrcibradic, D. and J. Niemeyer. 2013. Mabuya frenata, M. macrorhyncha. Tail bifurcation. Herpetological Review 44: 510-511. 